\title{
ACRL Officers for 1983-84
}

JOYCE BALL, university librarian at California State University (Sacramento, CA 95819), is the forty-sixth president of the Association of College and Research Libraries.

During her one-year term of office, she will preside over the ACRL Board of Directors and the ACRL Executive Committee. She will chair the ACRL Conference Program Planning Committee for the 1984 ALA Annual Conference in Dallas and will plan ACRL's major program at the conference.

As president of the di-

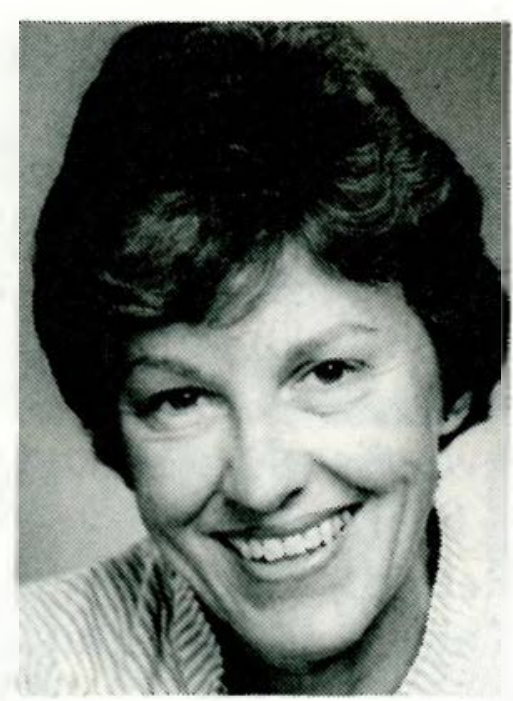

Joyce Ball vision, Ball will represent ACRL on the ALA Dallas Conference Program Committee. She will also represent ACRL and ALA in their relations with other organizations. Ball has been an active member of ACRL, serving as a director-at-large on the ACRL Board of Directors, a member of the College and Research Libraries Editorial Board, and a member of the Review Panel for the 1978 and 1981 ACRL National Conferences. She also served as president of the Nevada Library Association in 1978 and received a special citation from that association in 1980.

Sharon J. Rogers, associate dean of the Bowling Green State University Libraries (Bowling Green, OH 43403), has been elected vicepresident/presidentelect of the Association of College and Research Libraries. The 1983 election results showed 1,333 votes for Rogers and 893 for Keith $\mathrm{M}$. Cottam, director of the University of Wyoming Libraries, Laramie.

As vice-president/ president-elect of ACRL, Rogers will serve on the ACRL Board of Directors and the ACRL Exec-

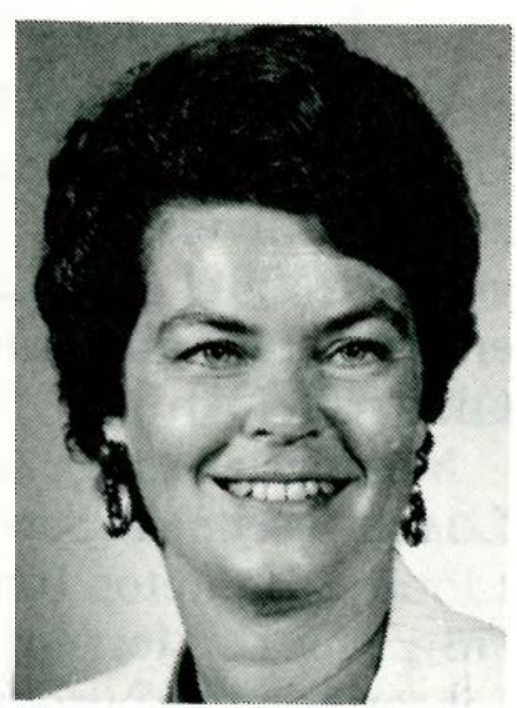

Sharon J. Rogers utive Committee. She will chair the ACRL Conference Program Planning Committee for the 1985 Annual Conference in Chicago. She will represent ACRL on the ALA Appointments Committee, the ALA Planning and Budget Assembly, and the ALA Conference Program Planning Committee for the 1985 conference. At the end of the 1984 Annual Conference, she will become ACRL's forty-seventh president.
Rogers has contributed to ACRL as a member of the ACRL Board of Directors, as chair of the Task Force on Academic Libraries and Higher Education, as chair of the Advisory Committee for the Bibliographic Instruction Liaison Project, and as chair of the Bibliographic Instruction Section (1980-1981). She currently serves as chair of the Legislation Subcommittee of the ALA Status of Women in Librarianship Committee, and as a member of the OHIONET On-Line Reference Council.

The results of the ACRL elections follow. For each position, the elected candidate is listed first. The number of votes earned by each candidate is listed in parentheses.

\section{Directors-AT-LARGE TO THE ACRL BoARd of Directors}

Director-at-Large, Chapters Council (four-year term): Boв D. CARMACK, Dean of Library Services, University of South Dakota, Vermillion, SD 57069 $(1,238)$; Rose M. Caruso, Assistant Director, University of Wisconsin College Library, Madison, WI 53706 (909).

Director-at-Large, Activity Sections (four-year term): AleXANDRA MASON, Spencer Librarian, Department of Special Collections, University of Kansas, Lawrence, KS 66045 (1,121); Mary Reichel, Head, Reference Department, Georgia State University, 100 Decatur St., S.E., Atlanta, GA 30303 (1,018).

\section{Anthropology and Sociology Section}

Vice-Chair/Chair-Elect: BonNIE R. Nelson, Reference Librarian, John Jay College of Criminal Justice, 445 W. 59th St., New York, NY 10012 (44); Lynne M. Schmelz-Keil, Reference and Audiovisual Librarian, Rutgers University, Newark, NJ $07102(24)$.

Secretary (two-year term): MaRvin D. LEAvy, Behavioral Sciences Librarian, Wichita State University Library, Wichita, KS 67208 (36); Christopher J. Busick, Anthropology and Economics Bibliographer, Norlin Library, University of Colorado, Boulder, CO 80309 (29).

\section{Whoops}

$C \downarrow R L$ News made an unfortunate error some years ago by mis-numbering the ACRL Presidents in the election results column. Carla J. Stoffle was the 45th ACRL President, not the 44th; David C. Weber was the 44th President, not the 43rd; and so on. Joyce Ball is now the 46th ACRL President. 
Member-at-Large (two-year term): LINDA KATZOFF-GrodOFSKY, Librarian for Anthropology and Sociology, Samuel Paley Library, Temple University, Berks \& 13th Sts., Philadelphia, PA 19122 (43); Hazel Johnson, Social Science Bibliographer, G27 Hillman Library, University of Pittsburgh, Pittsburgh, PA 15260 (22).

\section{Art Section}

Vice-Chair/Chair-Elect: GracEANNE A. DeCANDIDO, Coordinator, Archon Project, Bobst Library, New York University, New York, NY 10012 (75); write-in candidates (3).

Secretary (two-year term): D. Sherman Clarke, Head, Humanities Cataloging Team, 110 Olin Library, Cornell University Libraries, Ithaca, NY 14853 (54); Lisa Howorth, Reference/ Bibliographer, J.D. Williams Library, University of Mississippi, University, MS 38677 (26).

\section{Asian and African Section}

Vice-Chair/Chair-Elect: MarTha DukAS, Coordinator of Processing, Boston Public Library, P.O. Box 286, Boston, MA 02117 (57); Basima Q. Bezirgan, Middle East Cataloger, Joseph Regenstein Library, University of Chicago, 1100 E. 57th St., Chicago, IL 60637 (27).

Member-at-Large (three-year term): JoHN YUNG-HSIANG LaI, Associate Librarian, HarvardYenching Library, 2 Divinity Ave., Cambridge, MA 02138 (41); Joanne M. Zellers, African and Middle Eastern Specialist, African Section, Library of Congress, Washington, DC 20540 (31); Gia Aivazian, Librarian for Armenian and Greek, Research Library, University of California, Los Angeles, CA 90024 (12).

\section{Bibliographic InStruction Section}

Vice-Chair/Chair Elect: William Miller, Head, Reference Library, Michigan State University, East Lansing, MI 48824 (395); Beverly L. Renford, Reference Librarian, Hershey Medical Center Library, Hershey, PA 17033 (348).

Secretary (one-year term): Patricia M. BriL, Reference Librarian, California State University Library, P.O. Box 4150, Fullerton, CA 92634 (394); Roland C. Person, Assistant Undergraduate Librarian, Southern Illinois University, Carbondale, IL 62901 (329).

Member-at-Large (one-year term): Barbara J. WitTkopf, Associate Librarian, Department of Reference and Bibliography, University of Florida Libraries, Gainesville, FL 32611 (386); Claudette S. Hagle, Assistant Reference Librarian, Oklahoma State University Library, Stillwater, OK 74078 (314).

\section{College Libraries Section}

Vice-Chair/Chair-Elect: William A. MofFETT, Director of Libraries, Oberlin College, Oberlin, OH 44074 (247); Michael Haeueser, Director of Learning Resources, Gustavus Adolphus College,
St. Peter, MN 56082 (140).

Secretary (one-year term): JOANN H. LEE, Head, Reader Services, Lake Forest College Library, Lake Forest, IL 60045 (235); Larry L. Frye, Head Librarian, Lilly Library, Wabash College, Crawfordsville, IN 47933 (140).

\section{Community and Junior College LibraRIES SECTION}

Vice-Chair/Chair-Elect: ELINOR EBELING, Dean of Learning Resources, Brookdale Community College, Newman Springs Road, Lincroft, NJ 07738 (103); Iole Matteucig, Dean, Library Services, City College of San Francisco, 50 Phelan Ave., San Francisco, CA 94112 (88).

Secretary (one-year term): MILDRED KIRSNER, Reference Librarian, Miami Dade Community College, North Campus Library, 11380 N.W. 27th Ave., Miami, FL 33167 (98); Robert B. Ford, Chief Librarian, Medgar Evers College Library, 1150 Carroll St., Brooklyn, NY 11225 (94).

\section{Education and Behavioral SCIENCES SeCtion}

Vice-Chair/Chair-Elect: Thomas M. PeISCHL, Director of College Libraries and Computing Services, State University of New York College at Potsdam, Potsdam, NY 13676 (116); L. James Olivetti, Library Systems Analyst, Evaluation Technologies, Inc., 2020 N. 14th St., Arlington, VA 22201 (97).

Secretary (two-year term): ILENE F. ROCKMAN, Reference Librarian, Learning Resources and Curriculum Dept., California Polytechnic State University, San Luis Obispo, CA 93407 (139); Annette Buurstra, Education Librarian, Northeastern Illinois University Library, 5500 N. St. Louis Ave., Chicago, IL 60625 (79).

\section{Law and Political Science Section}

Vice-Chair/Chair-Elect: Peter Malanchuk, Chairman, Department of Reference and Bibliography, University of Florida Libraries, Gainesville, FL 32611 (71); Laurene E. Zaporozhetz, Reference Librarian, University of Oregon, Eugene, OR 97403 (33).

Member-at-Large (one-year term): MARVA DELOACH, Technical Services Librarian, Huntington Library, Hampton Institute, Hampton, VA 23668 (73); Ray L. Morrison, Bibliographic Instruction Librarian, Pittsburg State University, Pittsburg, KS 66762 (31).

\section{Rate Books AND \\ ManusCRIPTS SECTION}

Vice-Chair/Chair-Elect: LINDA CoREY ClaASSEN, Coordinator, Center for the Book, Library of Congress, Washington, DC 20540 (191); David Farmer, Director, Rare Books and Special Collections, University of Tulsa, 600 S. College Ave., Tulsa, OK 74104 (132).

Secretary (two-year term): ANTHONY BLISS, Rare 


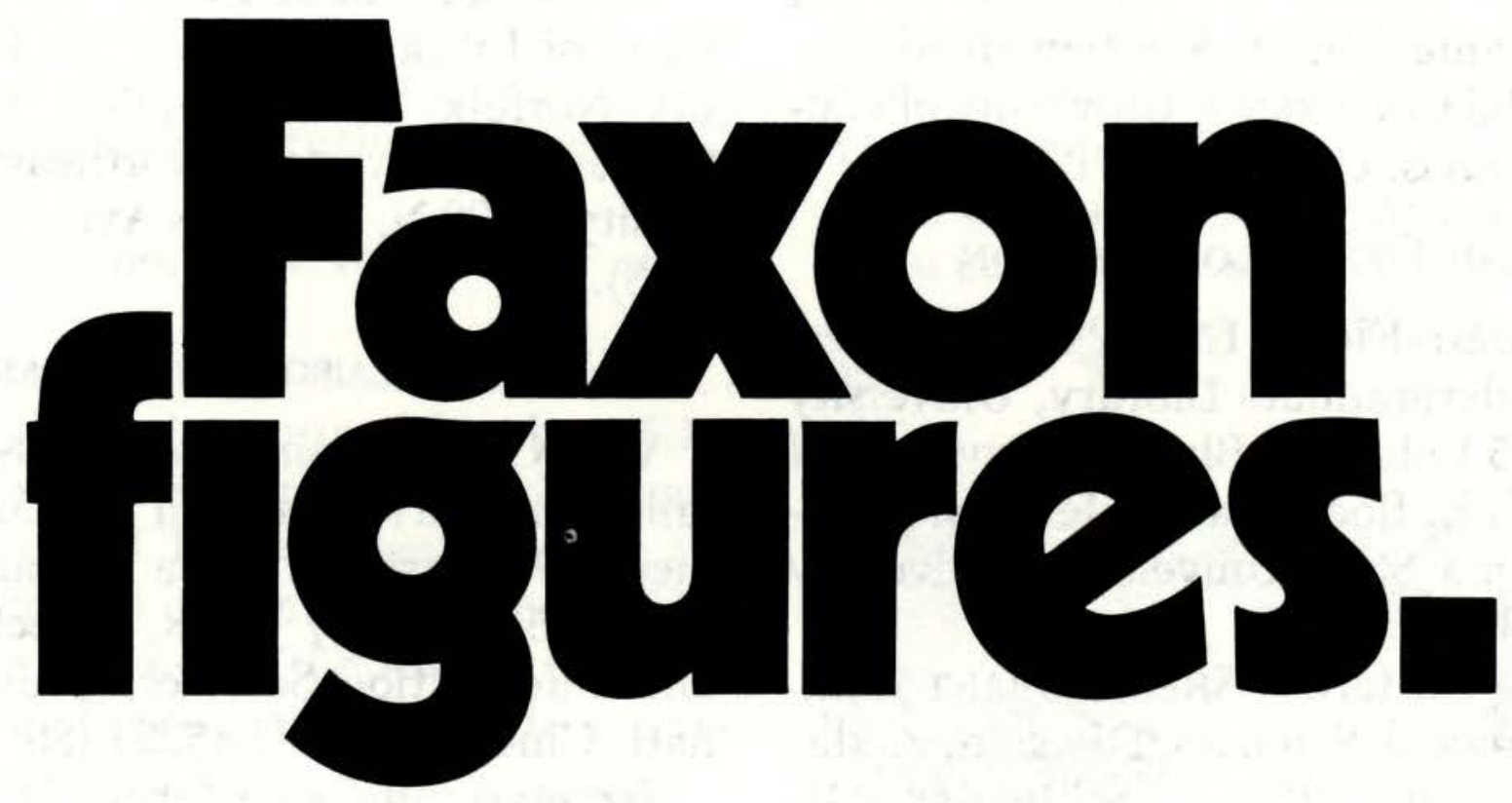

Productivity is a critical concern in today's library. That's why more and more decision makers are looking into Faxon. We can be the best source for all of your journal and continuation subscriptions. Our services enable you to devote your valuable personnel resources to other crucial library functions.

As a full service agent with access to more than 150,000 different periodicals, we can handle ordering, claiming, check-in, and routing. Our growing international network links you to other libraries, publishers, and in the near future, other online systems.

If you can profit from improved productivity, a call to Faxon figures.

1-800-225-6055

or 1-617-329-3350 (collect)

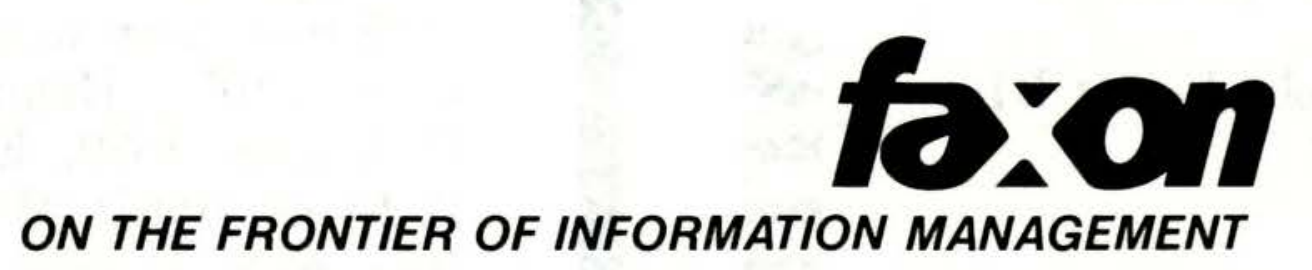

F.W. Faxon Company, Inc. 15 Southwest Park Westwood, MA 02090 
Book Librarian, Bancroft Library, University of California, Berkeley, CA 94720 (200); David S. Zeidberg, Curator of Special Collections, Gelman Library, George Washington University, Washington, DC 20052 (114).

Member-at-Large (three-year term): JENNIFER B. LEE, Reference Librarian, Library Company of Philadelphia, 1314 Locust St., Philadelphia, PA 19107 (196); C. Danial Elliott, Assistant Head, Department of Special Collections, University of California Library, Davis, CA 95616 (119).

\section{SCIENCE ANd Technology Section}

Vice-Chair/Chair-Elect: LINDA L. PhILlips, Acting Head, Undergraduate Library, University of Tennessee, 1015 Volunteer Blvd., Knoxville, TN 37996 (135); Keith E. Roe, Head, Life Sciences Library, Pennsylvania State University, University Park, PA 16802 (111).

Secretary (one-year term): ShEILA GRANT JoHNson, Head, Biological Sciences Division, Oklahoma State University Library, Stillwater, OK 74078 (142); Martin Kesselman, Life Sciences Librarian, Coles Science Center, Bobst Library, New York University, New York, NY 10012 (102).

\section{Slavic and East European Section}

Vice-Chair/Chair-Elect: LASZlo Kovacs, Head, Humanities Library, Purdue University, West Lafayette, IN 47907 (19); Ivan L. Kaldor, Professor, School of Library and Information Science, State University College of Arts and Science, Geneseo, NY 14454 (15).

Member-at-Large (one-year term): DonNA A.

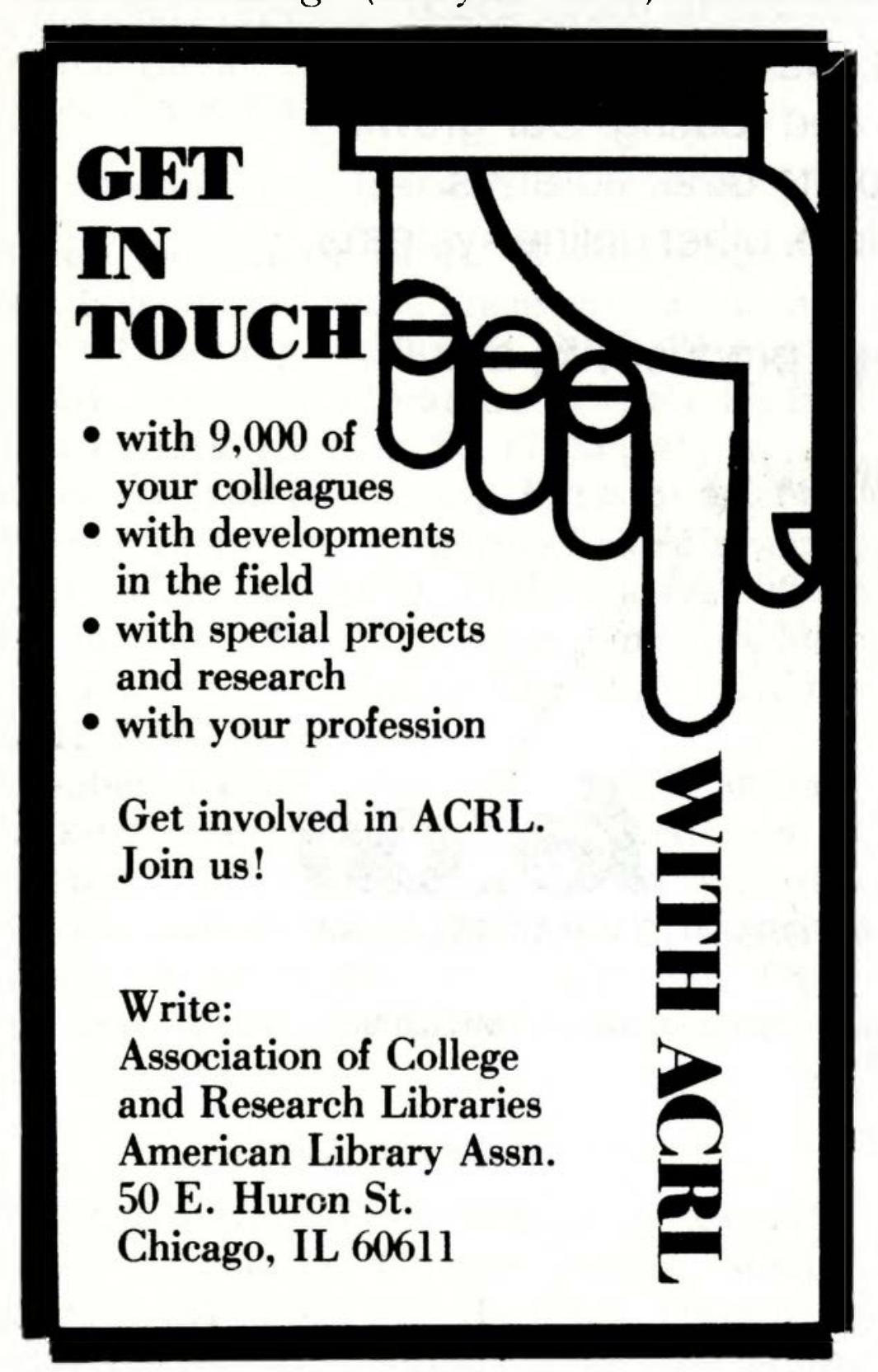

CANEVARI, Slavic Bibliographer, University of Saskatchewan, Saskatoon, Saskatchewan, Canada S7N 0W0 (18); Dennis Kimmage, Senior Assistant Librarian, Feinberg Library, State University College, Plattsburgh, NY 12901 (17).

\section{University LiBRARIES SECTION}

Vice-Chair/Chair-Elect: Cynthia B. Duncan, Dean of Library Services, Old Dominion University, Norfolk, VA 23508 (733); Melvin L. George, University Librarian, Northeastern Illinois University, 5500 N. St. Louis Ave., Chicago, IL 60625 (508).

\section{Western European Specialists Section}

Vice-Chair/Chair-Elect: Ross Atkinson, Assistant University Librarian for Collection Development, University of Iowa Library, Iowa City, IA 52242 (56); Cicely Johns, Director of Collections and Information Services, University of Cincinnati, Cincinnati, OH 45221 (29).

Secretary (one-year term): JEFFRY LARSON, Humanities Bibliographer, Yale University Library, Box 1603A Yale Station, New Haven, CT 06520 (57); Fred J. Gitner, Librarian, French Institute/Alliance Française Library, 22 E. 60th St., New York, NY 10022 (31).

Member-at-Large (one-year term): MARJORIE A. BENEDICT, Bibliographer, UL 228, State University of New York, 1400 Washington Ave., Albany, NY 12222 (53); Laszlo Kovacs, Head, Humanities Library, Purdue University, West Lafayette, IN 47907 (32).

\section{ACADEMIC/RESEARCH LIBRARIAN OF THE YEAR AWARD}

The Association of College and Research Libraries invites nominations for the Academic or Research Librarian of the Year Award, presented jointly by ACRL and the Baker \& Taylor Company. Anyone wishing to submit nominations should send the form on the following page to the ACRL Office, 50 E. Huron St., Chicago, IL 60611.

Recipients of the award since its inception in 1978 have been Keyes D. Metcalf and Robert B. Downs (1978); Henriette D. Avram and Frederick G. Kilgour (1979); Evan I. Farber (1980); Beverly P. Lynch (1981); William Budington (1982); and Richard M. Dougherty (1983).

The Award Committee selects persons to receive the award in accordance with the following guidelines:

PURPOSE: To recognize an individual member of the library profession who has made an outstanding national or international contribution to academic or research librarianship and library development. 
Criteria: Individuals nominated should have demonstrated achievements in such areas as:

1. Service to the organized profession through ACRL and related organizations.

2. Significant and influential research on academic or research library service.

3. Publication of a body of scholarly and/or theoretical writing contributing to academic or research library development.

4. Planning and implementing a library program of such exemplary quality that it has served as a model for others.

5 . Nominee does not have to meet all of the above criteria.

RuLES: The award shall be made each year at a time and place to be determined by the ACRL Board of Directors. Announcement of the award shall be made by the ACRL president at a time and place to be determined by the ACRL Board of Directors. If, in the opinion of the Award Committee, no worthy candidate is nominated in a given year, the award will not be presented that year.

Nominations: Nominations for the award must be returned to the chair of the Academic/Research Librarian of the Year Award Committee and must be postmarked no later than December 1, 1983. Nominations must be submitted in quintuplicate and should be accompanied by a statement of supporting reasons and a copy of the nominee's resume. Please do not solicit supporting letters seconding your nomination. Such letters will not be considered in the Award Committee's decision.

Nature OF THE AWARD: The Academic/Research Librarian of the Year Award shall consist of \$2,000 and an appropriate citation.

The Award Committee for 1983 consists of the following persons: Kenneth G. Peterson (chair), Dean of Library Affairs, Morris Library, Southern Illinois University, Carbondale, IL 62901;
Henriette D. Avram, Director for Processing Systems, Networks and Automation Planning, The Library of Congress, Washington, DC 20540; Mary Sue Ferrell, Assistant to the Dean of Instruction, Western Nevada Community College, 2201 W. Nye Lane, Carson City, NV 89701; Doralyn J. Hickey, Professor, School of Library and Information Sciences, North Texas State University, Denton, TX 76203; Jane Ross Moore, Graduate School and University Center, City University of New York, 33 West 42d Street, New York, NY 10036; and Patricia G. Oyler, Associate Professor, Simmons College, Graduate School of Library and Information Science, 300 The Fenway, Boston, MA 02115 .

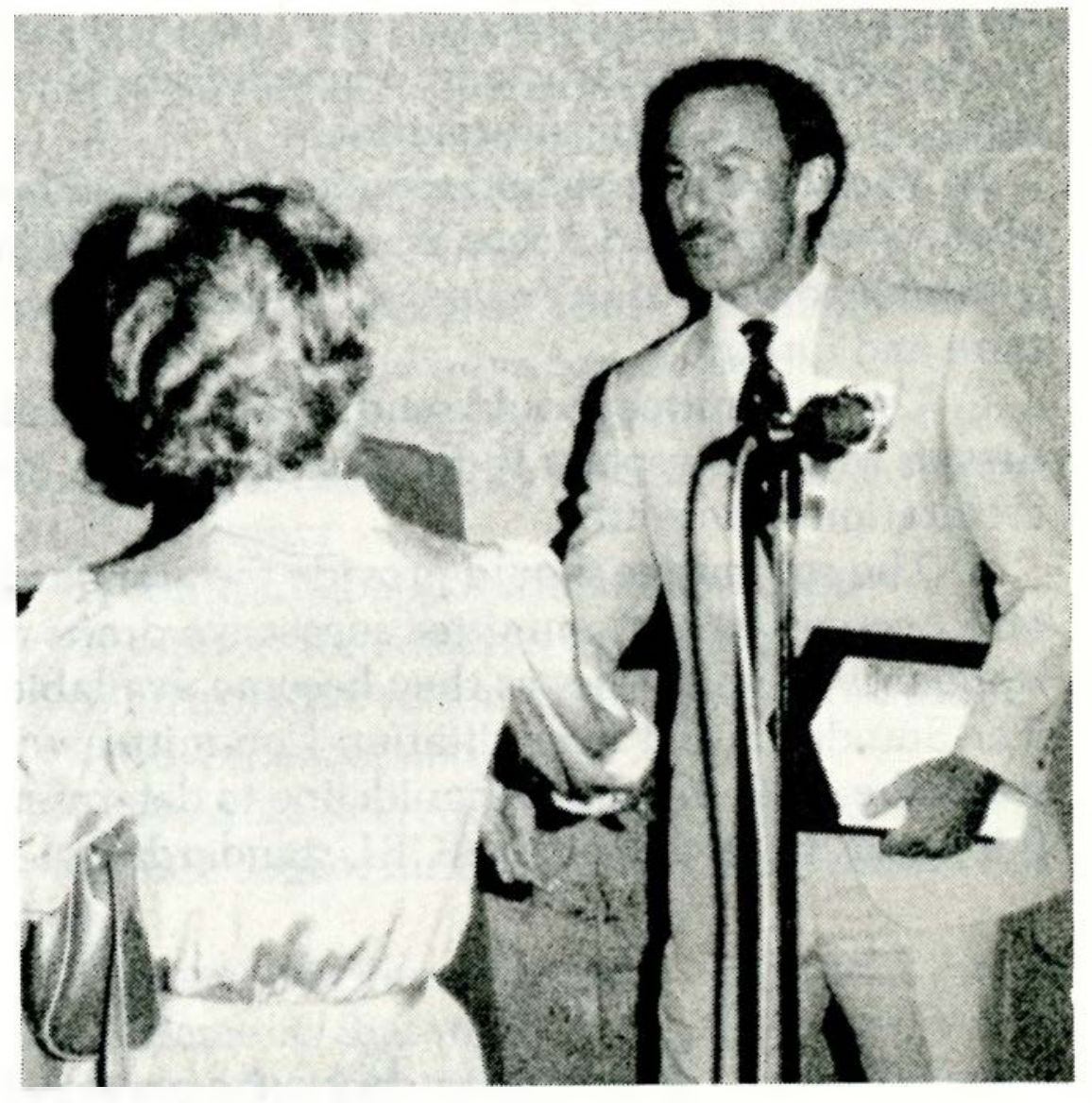

Richard M. Dougherty receives the 1983 Award in Los Angeles.

I nominate

(name and present address)

(Please list achievements of your nominee on a separate sheet.)

Nominated by

Address

Please return no later than December 1, 1983, to:

Academic or Research Librarian Award

Association of College and Research Libraries, ALA

50 East Huron Street

Chicago, IL 60611 


\section{Procedures for Reviewing and Approving ACRL Standards and Guidelines}

Editor's Note: These procedures, prepared by the ACRL Standards and Accreditation Committee, were approved by the ACRL Board of Directors at ALA Annual Conference in Los Angeles.

To enable the Standards and Accreditation Committee to fulfill its charge, ACRL committees and sections that are developing or revising standards or guidelines should follow these procedures.

a) A decision by any ACRL Section or the Board to establish or charge a committee to develop or to revise standards or guidelines should be forwarded to the ACRL Standards and Accreditation Committee in writing, for information.

b) The committee should request that a member of the Standards and Accreditation Committee be available to assist as necessary on matters of procedure and format.

c) The committee should send copies of its minutes or progress reports to the Standards and Accreditation Committee.

d) The committee should provide the Standards and Accreditation Committee successive drafts of standards or guidelines as they become available. The Standards and Accreditation Committee will study the draft standard or guideline to determine if it is consistent with other ACRL standards and in compliance with the ALA Standards Manual. If the Standards and Accreditation Committee has any concerns, they will respond to the section or committee with specific comments or suggestions by the next conference.

e) Upon receipt of the final draft of a standard or guideline and after a final review in relation to current ACRL standards and the ALA Standards Manual, the Standards and Accreditation Committee will recommend acceptance or nonacceptance of the standard or guideline to the ACRL Board and, at the same time, notify the section or committee who initiated the standard or guideline of its action.

f) If the ACRL Board approves the standard or guideline, it will be forwarded to the ALA Standards Committee for its review and approval.

g) If an ACRL section or committee develops a standard with another organization, it may be necessary to adjust the timetable for review.

The Standards and Accreditation Committee will review approved ACRL standards and guidelines periodically for continued relevance or suggest new ideas for which standards or guidelines should be developed and recommend action as necessary to the appropriate ACRL unit.

\section{Policy Statement on Publication of Conference Papers of ACRL Sections}

Editor's Note: This statement, developed by the ACRL Publications Committee, was approved by the ACRL Board of Directors at ALA Annual Conference in Los Angeles.

One of the purposes of ACRL is to promote and disseminate its members' and sections' work in the fields of their expertise. Its publication program is one major means of engaging in this promotion and dissemination. This Policy Statement sets forth a procedure by which its sections and ACRL approach the publication process.

A section which wishes to publish its conference proceedings or papers will submit its manuscript to ACRL. In order that ACRL have a reasonable time to decide whether to publish the manuscript, it shall have four months after its receipt to report a decision; otherwise, the section shall be free to have its manuscript published elsewhere.

Points of discussion between the section and the prospective publisher may include:
1. Proposed publication date.

2. Format, including any particular needs regarding illustrations or typography.

3. Arrangement of bibliographical references, i.e., footnotes or endnotes.

4. Paper stock.

5. Binding.

6. Maximum sale price.

7. Minimum period during which the volume will remain in print.

8. Advertising (number of ads which will coincide with the date of publication).

9 . Number of review copies to be provided by the publisher.

10. Date by which the section will deliver the final manuscript to the publisher.

11. Size of print run.

12. Number of offprints for authors and a copy of the book for the editor.

The copyright will be retained by ALA, with each author retaining the right to subsequent use of 
the author's work in any publication under his or her authorship or editorship.

Any volume issued by a commercial publisher must clearly state on the title page and in the preface or introduction that the conference papers being published were presented at a meeting of an ACRL section.

If ACRL decides to publish the volume, then a $7 \%$ royalty shall be divided among the responsible authors and editors. If ACRL does not publish the volume, of the royalties, $60 \%$ shall be divided among the responsible authors and editors and $40 \%$ shall be realized by ACRL.

In cases where the publisher is not ACRL, the Executive Director of ACRL must have the opportunity to review any contracts between an ACRL section and a publisher to ensure that all provisions of this Policy Statement have been met.

\section{Manuscripts and Projects Wanted}

Do you have some research that deserves to be published? College \& Research Libraries would like to consider your manuscript. ACRL's refereed journal includes articles in all fields of interest and concern to academic and research librarians-for example, library collections, their acquisition and organization; services to readers and bibliographic instruction; library organization and management; special collections; library history. Case studies, narratives, informed editorial opinions, and reports on controlled research projects are all welcome. Shorter manuscripts will be considered for $C \triangleleft R L$ 's Research Notes section.

Submit all materials to the editor, C. James Schmidt, c/o Research Libraries Group, Jordan Quadrangle, Stanford, CA 94305.

If your research is comprehensive enough for a book, you may submit query letters or manuscripts to the editor of ACRL's Publications in Librarianship series, Arthur P. Young, Dean of Libraries, University of Rhode Island, Kingston, RI 02881.

Films, videotapes, slide-tape productions, audiocassettes, and other nonprint media are welcomed for consideration by the ACRL Nonprint Publications series. Submit your scripts, samples, or other materials to the editor, Jean W. Farrington, Assistant Circulation Librarian, Van Pelt Library, University of Pennsylvania, Philadelphia, PA 19104.

And don't forget that College \& Research Libraries News would like to hear of any research in progress, grants for research, or news in general about you and your library. Write or call the editor, George M. Eberhart, C $b R L$ News, ACRL/ALA, 50 East Huron St., Chicago, IL 60611; (312) 944-6780, ext. 288.
STATUS STATEMENTS

The ACRL Academic Status Committee, in response to a request from the ACRL Standards and Accreditation Committee, is in the process of reviewing the six standards and guidelines that have been developed previously by the committee. The statements to be reviewed are: Guidelines and Procedures for the Screening and Appointment of Academic Librarians (C $b R L$ News, September 1977); Joint Statement on Faculty Status of College and University Librarians (C\&RL News, February 1974); Model Statement of Criteria and Procedures for Appointment, Promotion in Academic Rank, and Tenure for College and University Librarians (CむRL News, September and October 1973); Standards for Faculty Status for College and University Librarians (C\&RL News, May 1974); Statement on Collective Bargaining (1975, availabie from ACRL); and Statement on the Terminal Professional Degree for Academic Librarians (1975, available from ACRL). Your comments on these standards and guidelines are welcome.

The ACRL Academic Status Committee is also beginning to draft policy statements on several additional topics:

1) continuing appointments for librarians;

2) support for research by librarians;

3) affirmative action and equal opportunity;

4) governance; and

5) the ALA-accredited master's degree as an appropriate degree for the director of an academic library.

Anyone who has comments, suggestions, or policy statements that might be of assistance in drafting these statements is invited to forward them to the Committee. Suggestions of other topics for statements that might be developed would also be of interest. Send your suggestions to: Barbara J. Ford, Chair, ACRL Academic Status Committee, Library, Box 8198, University of Illinois at Chicago, Chicago, IL 60680; (312) 996-2738.

\section{Tips Needed}

The ACRL Education and Behavioral Sciences Section's Bibliographic Instruction for Educators Committee is drafting a "BI Tip Sheet for Academic Administrators and Support Staff." The document is intended for librarians and will provide suggestions on publicizing, presenting, and evaluating library workshops for secretaries, administrators, counselors, and other non-faculty personnel.

The Committee would like to hear of your experiences. Write to: Charles Thurston, Chair, ACRL/EBSS/BIE Committee, University of Texas at San Antonio Library, San Antonio, TX 78285. 


\section{ACRL/ISI FELLOWSHIPS FOR 1984}

The Association of College and Research Libraries solicits applications for two fellowships made possible by the Institute for Scientific Information of Philadelphia. The first, the Samuel Lazerow Fellowship for Outstanding Contributions to Acquisitions or Technical Services in an Academic or Research Library, honors a senior vicepresident of ISI who made outstanding contributions to these fields. The fellowship of $\$ 1,000$ is to foster advances in acquisitions or technical services by providing a practicing librarian with funds for research, travel, or writing.

The second fellowship, the ACRL Doctoral Dissertation Fellowship, provides an award of $\$ 1,000$ to a doctoral student working on a dissertation in the area of academic librarianship.

Applications for both fellowships should be made to Sandy Whiteley, Program Officer, ACRL/ALA, 50 E. Huron St., Chicago, IL 60611, and are due by December 1, 1983. The winners of the awards will be announced at the ALA Annual Conference in Dallas in June, 1984.

To be eligible for the Lazerow Award, a librarian must be working in acquisitions or technical services in an academic or research library. Application proposals should be brief (five pages or less) and include the following:

1. Description of research, travel, or writing project;

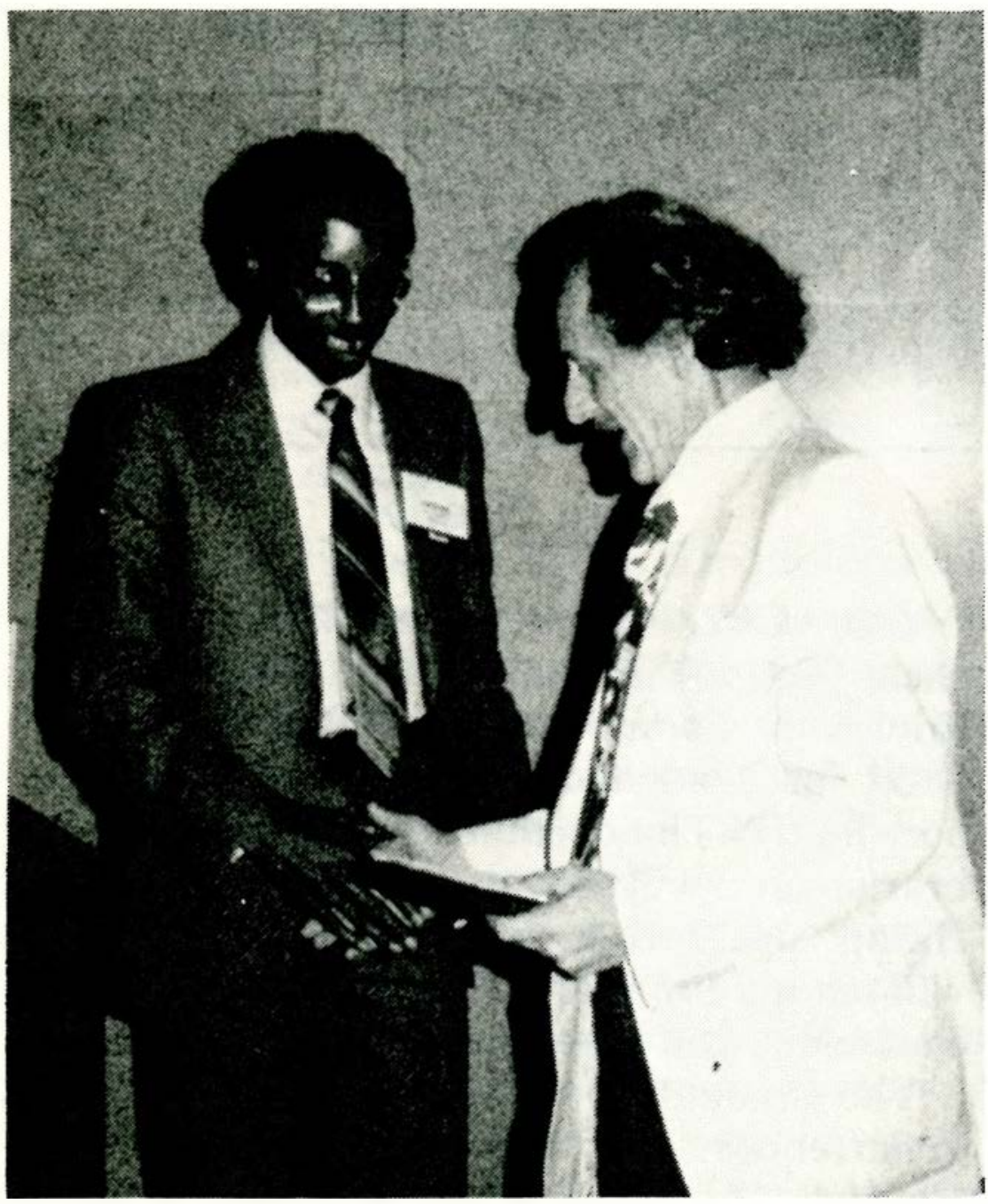

2. Schedule for the project;

3. An estimate of expenses.

An up-to-date curriculum vitae should accompany the proposal. Proposals for the Lazerow Award will be judged on the following:

1. Potential significance of the project to acquisitions or technical services work;

2. Originality and creativity;

3. Clarity and completeness of the proposal;

4. Evidence of an interest in scholarship, such as a previous publication record.

The winner of the 1983 Fellowship was Denise Bedford, formerly of Stanford University.

In order to be eligible for the ACRL Doctoral Dissertation Award, the applicant must meet the following qualifications:

1. Be an active doctoral student in the academic librarianship area in a degree-granting institution;

2. Have all course work completed;

3. Have had a dissertation proposal accepted by the institution.

The application should be brief (less than ten pages) and include the following:

1. Description of the research, including significance and methodology;

2. A schedule for completion;

3. Budget and budget justification for items for which support is sought (these must be items for which no other support is available);

4. The name of the dissertation advisor and committee members;

5. A cover letter from the dissertation advisor endorsing the proposal.

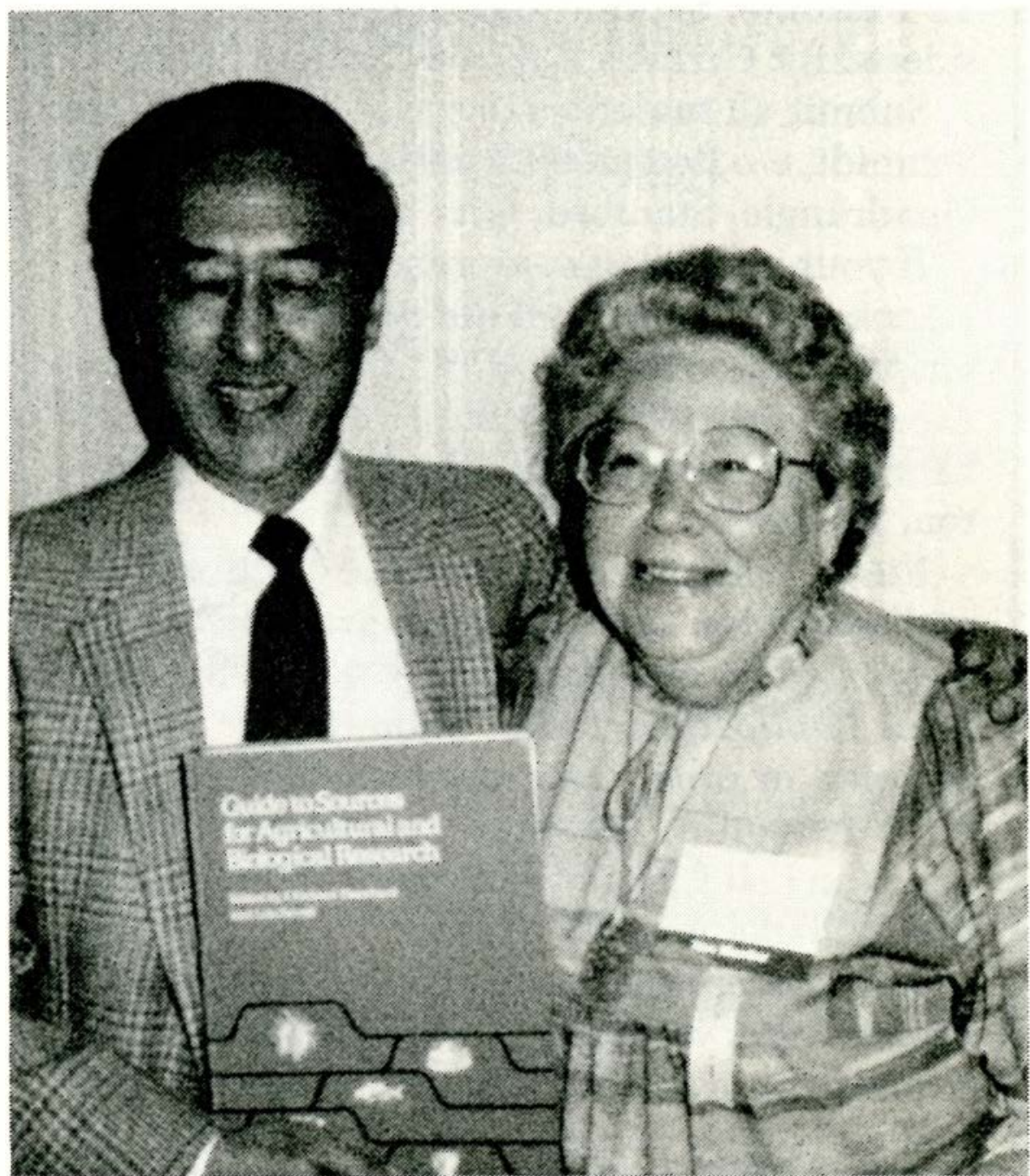

Awards at Annual Conference: Left, Eugene Garfield of ISI (r) presents Stanton Biddle (l) with the Dissertation Fellowship. Right, Lois Farrell (r), co-author of the Oberly Award-winning bibliography in agriculture, stands with Ming-Yu Li (l), who accepts the award for co-author J. Richard Blanchard. 


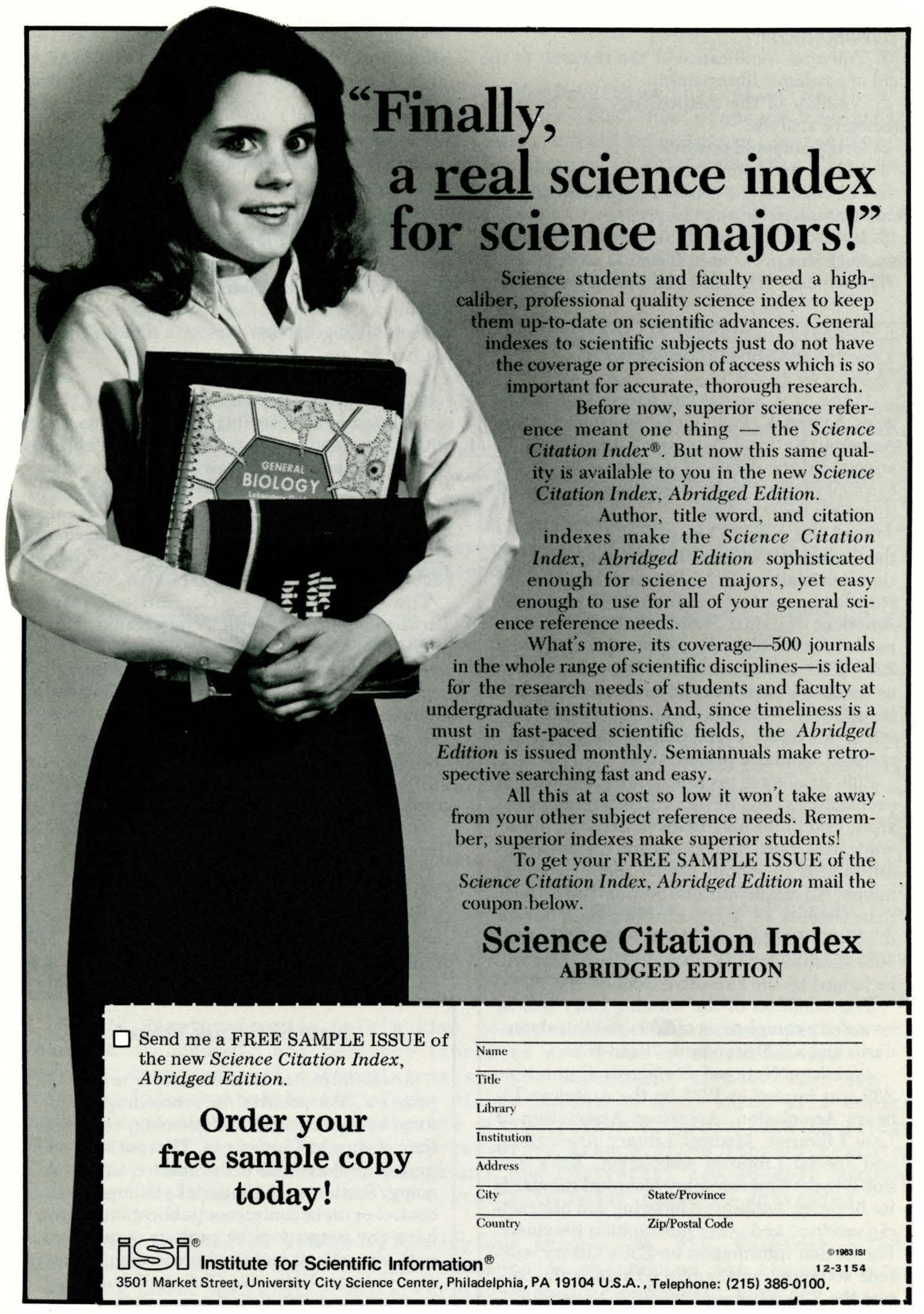


An up-to-date curriculum vitae should accompany the proposal. Proposals will be judged on the following criteria:

1. Potential significance of the research to the field of academic librarianship;

2. Validity of the methodology and proposed method of analysis;

3. Originality and creativity;

4. Clarity and completeness of the proposal;

5. Presentation of a convincing plan for completion in a reasonable amount of time;

6. Evidence of a continuing interest in scholarship, such as a previous publication record.

The winner of the 1983 Fellowship was Stanton

\section{Name an Association}

At the ALA Annual Conference in Los Angeles, Sandra K. Paul, chairperson-elect of the American National Standards Committee Z39, announced the details of a nationwide contest to solicit suggestions for a new name for the Z39 standards organization.

Until this year Z39 existed as an activity of the Council of National Library and Information Associations (CNLIA) and reported on standards matters through CNLIA to the American National Standards Institute. As a result of joint planning between CNLIA and Z39, Z39 now has achieved independent status as an educational association incorporated in the District of Columbia. In this capacity Z39 will seek a direct relationship to ANSI as an accredited standards organization.

Z39, as always, seeks to utilize the skills of professionals from the library, information services, and publishing fields in carrying out its work. Interested individuals and organizations are invited to submit one or more suggested names. All entries must be postmarked no later than October 15, 1983. Entries should be sent to: ANSC Z39 Name Contest, NBS, Library E106, Washington, DC 20234. The entries will be judged by the Executive Council of Z39.

The submitter of the winning entry will be awarded a complete set of Z39's published standards and a Z39 Standards "Bear-er".

American National Standards Committee Z39 was formed in 1938 by the American Library Association, American Association of Law Libraries, Medical Library Association, and Special Libraries Association. Z39's mission is to develop voluntary technical standards for libraries, publishers, indexing and abstracting services, and other information providers. For further information on Z39's history, current activities, and published standards, contact the Z39 offices: ANSC Z39, National Bureau of Standards, Library E-106, Washington, DC 20234; (301) 921-3241.
Biddle, a doctoral candidate at the University of California, Berkeley.

For further information on either of these two fellowships, contact Sandy Whiteley, ACRL/ALA, 50 E. Huron St., Chicago, IL 60611; (312) 9446780 .

\section{CENKO PRIZE}

The Harvard Ukrainian Research Institute is accepting submissions for the fourth award of the Cenko Prize in Ukrainian Bibliography. The $\$ 1,000$ annual prize established by Mykola and Volodymyra Cenko of Philadelphia will be given for the best bibliographical work on a topic of Ukrainian studies.

Entries-in English or in Ukrainian-must be submitted in four copies by March 1, 1984. Manuscripts must be in their final prepublication form, with names and addresses of authors. Published works and late submissions will not be considered.

Examples of solicited entries are: descriptive bibliographical essays or annotated bibliographies of a subject or author; index of a Ukrainian periodical; or more general works which discuss the impact of the printed book on Ukrainian culture.

The Cenko Prize Committee (Marta Tarnawsky, University of Pennsylvania, Chairman; Osyp Danko, Yale University; and Edward Kasinec, University of California at Berkeley, members) will judge the entries according to the following criteria:

1) importance and originality of the topic;

2) the work's methodology and completeness;

3) the work's contribution to existing bibliographical scholarship.

The winner or winners will be announced at Harvard University no later than June, 1984.

Entries should be sent by registered mail to: Cenko Prize in Ukrainian Bibliography, Harvard University, Ukrainian Research Institute, 15811583 Massachusetts Ave., Cambridge, MA 02138 .

\section{New STS Task Force}

A task force has been formed to review the program, Perspectives on Proceedings, sponsored by the Science and Technology Section at the Los Angeles Conference. The task force will suggest projects which the Science and Technology Section might undertake to improve the control or use of conference publications. If you have any suggestions on projects or problems with scientific or technical proceedings, please send them to: Katherine Chiang, Entomology, Fisheries and Wildlife Library, 375 Hodson Hall, 1980 Folwell Avenue, St. Paul, MN 55108 . 